\author{
D. Filyanin, assistant, ORCID 0000-0003-3576-3633 \\ National Technical University of Ukraine «Igor Sikorsky Kiev Polytechnic Institute»

\section{IDENTIFICATION OF HARMONIC DISTORTION SOURCES IN DISTRIBUTION SYSTEMS USING THE DISCRETE FOURIER TRANSFORM ON PERIODS}

\begin{abstract}
The presence of non-linear loads and the increase in the number of systems of distributed generation of electricity lead to a distortion of the voltage and current waveform in distribution systems (DS), mo ecmb $\kappa$ появлению гармоник тока и напряжения. In this case, the power system is obliged to supply electricity only to the fundamental frequency of $50 \mathrm{~Hz}$ with constant amplitude. Power supply organizations usually disclaim responsibility for the causes of harmonics by introducing standards or recommendations for limiting the levels of harmonic components in the points of common connection of consumers. These documents do not take into account the composition of DS equipment and, accordingly, the damage from this harmonics for network equipment and consumer equipment. The urgency of the work is due to the need to reliably identify the sources of harmonic distortion in the supply system for the effective functioning of the system of penalties and fines and to more effectively determine the list of measures to improve the electric power quality. The paper reviews the existing methods for distortion sources identification in supply systems. In most cases, the fast Fourier transform (FFT) is used as a method of harmonic analysis to determine the sources of distortion, which in the case of a rapidly changing non-linear load does not reliably determine the sources of distortion and the degree of participation of each DS's subject in the power distribution of higher harmonics. In order to detail the frequency content of the signal at the measurement interval, the spectral points obtained as a result of the FFT were calculated using the Discrete Fourier Transform (DFT). A new approach to the harmonic sources identification is proposed using a method based on the measurement of harmonic power flux sense using the Discrete Fourier Transform on periods by the example a distribution network model.

Key words: power quality, harmonics, nonsinusoidal conditions, harmonic ratio, identification of distortion source, Fast Fourier Transform, Discrete Fourier Transform.
\end{abstract}

Introduction. The presence of nonlinear loads and the growth of the number of distributed generation systems lead to a distortion voltage and current waveform in the distribution systems (DS), i.e., to the appearance of current and voltage harmonics. But power system is duty to supply electric power only on the fundamental frequency $50 \mathrm{~Hz}$ with constant amplitude.

The problem of harmonics in DS is not new. As early as the 30s of the 20th century, distortions current and voltage waveform were observed in the generators. The impact of harmonics is entails a malfunction of the power equipment and harmful effects on consumers' electrical receivers. Some effects of harmonics [1,2]:

1. Outage of capacitor banks. When the harmonics exceed the allowable levels, the capacitor banks do not change their characteristics, but they quickly fail.

2. Influence on power line communication. Harmonics is interference for the carrier frequency of power line communication transmitting equipment, which causes data loss and incorrect operation of remote equipment using this type of communication.

3. Increased power loss and overheating of synchronous and asynchronous machines.

4. Increasing voltages or currents harmonic in the distribution network due to series or parallel resonances.

5. Cable insulation fault as a result of overvoltages caused by harmonics.

6. Interference for telecommunication.

7. Effect on the accuracy of metering devices. [3].

8. Malfunctions of protection devices or decline of their characteristics. Semiconductor and microprocessor systems are particularly sensitive to harmonics.

9. Influence on frequency-regulated drives and excitation systems of power plant generators.

10. Shaft vibration of asynchronous and synchronous machines.

11. Unstable operation of digital relays using algorithms based on the analysis of a sample of data or the

(с Д.В. Філянін, 2018 
determination of the zero crossing voltage or current.

The effects of harmonics impact also depend on the harmonic sources, its location in the DS and the characteristics of the network [1]. The same harmonics from different sources can produce a different effect, depending on their phase with respect to the fundamental [2].

According to European research institutions, as a result of the low quality of electrical energy in industry, there is a loss of more than 150 billion euros per year. Of these, harmonic effects account for 1.3 billion euros [4]. But if we take into account the impact of harmonics on the relay protection equipment and the possible outages of consumers, the losses can amount to more than 100 billion euros [4].

Energy supply organizations usually disclaim responsibility for the causes of the appearance of harmonics, introducing standards or recommendations to limit the levels of harmonic at the point of common connection [2]. These documents do not take into account the type of the DS equipment and, accordingly, the damage that harmonics can cause to network equipment and consumer equipment.

Losses subjects of the process of distribution of electrical energy from the decline of its quality in excess of permissible rates [5], must be paid by the distortion sources. For this, it is necessary to determine the harmonic sources and to assess the degree of participation of each to stimulate the distortion sources to install compensating equipment with the help of a system of penalties and fines.

Analysis of references. There is not yet available a generalized method that can provide distortion sources detection [6].

In the references [7-12] two groups of approaches to the distortion sources detection of the voltage waveform at the point of common connection (PCC) are distinguished [13]:

1. A group based on measurements in the PCC with known or unknown impedance of the network and the consumer;

2. A group based on measurements taken at different points in the supply system, using state estimation techniques [14].

The second group of approaches for detection of harmonic sources is used for transmission lines and includes complex algorithms for optimizing the placement of sensors throughout the power supply system for distortion sources assessment (for example, [15]).

We are interested in the distribution network, in which a tree-shape structure with a single power source distinguishes them from complex-closed transmission lines and determines the direction of the power flux of the fundamental harmonic [16]. Since it is necessary to monitor each subject of the DS (by analogy with energy metering), the issue of optimizing the location of metering devices points is not put.

Let's consider the methods of the distortion sources detection related to the first group:

1. Methods based on harmonic power flux sense [17]:

$$
P_{i}=\frac{U_{i c} I_{i c}+U_{i s} I_{i s}}{2} \quad Q_{i}=\frac{U_{i c} I_{i s}-U_{i s} I_{i c}}{2},
$$

where $P_{i}, Q_{i}$ - active and reactive power of the $i$-th harmonic; $U_{i c}, U_{i s}$ - the cosine and sine components of the amplitude of the $i$-th harmonic of voltage; $I_{i c}, I_{i s}$ - the cosine and sine components of the current amplitude of the $i$-th harmonic.

2. The method of the deforming and non-deforming load [18], according to which the measured current $i(t)$ the sum of the non-deforming $i_{n}(t)$ and deforming $i_{d}(t)$ currents:

$$
\begin{gathered}
i_{n}(t)=\sum_{k=1}^{n} \frac{I_{1}}{U_{1}} \sqrt{2} U_{k} \sin \left(k \omega_{1} t+\theta_{k}+k\left(\phi_{1}-\theta_{1}\right)\right) \\
i_{d}(t)=i(t)-i_{n}(t)
\end{gathered}
$$

where $U_{1}, I_{1}-$ rms voltage and current of the first harmonic; $\theta_{1}, \phi_{1}$ - the phase angles of the current and voltage first harmonic; $\theta_{k}$, the phase angle of the $k$-th voltage harmonic.

3. Method of distorting and non-distorting current [19]. The load is represented as an equivalent linear resistance to the first harmonic:

$$
Z_{1}=\frac{U_{1}}{I_{1}},
$$

where $U_{1}, I_{1}$ - the rms voltage and current of the first harmonic, measured in the PCC.

Then:

$$
R=\left|Z_{1}\right| \cos \varphi_{1}, X_{1}=\left|Z_{1}\right| \sin \varphi_{1},
$$




$$
L=\frac{X_{1}}{2 \pi f_{1}}
$$

where $R$ - the active component of the load impedance; $X_{1}$ - the reactance load to the first harmonic; $\varphi_{1}-$ the phase difference between the voltage and current vectors of the first harmonic, $f_{1}$ - the frequency of the network $(50 \mathrm{~Hz}), L-$ the inductance of the load.

Load reactance to harmonic components:

$$
X_{k}=2 \pi k f_{1} L,
$$

where $k$ - the order of the harmonic.

Without considering skin effect and supposing $R$ independent on frequency:

$$
\begin{gathered}
\left|Z_{k}\right|=\sqrt{R^{2}+X_{k}^{2}} \\
\varphi_{k}=\operatorname{tg}^{-1} \frac{X_{k}}{R}
\end{gathered}
$$

Current consumed by the ideal linear load:

$$
i_{L}(t)=\sum_{k=1}^{n} \frac{U_{k}}{\left|Z_{k}\right|} \sqrt{2} \sin \left(2 \pi k f_{1} t+\left(\theta_{k}-\varphi_{k}\right)\right)
$$

where $\theta_{k}$-the phase angle of the $k$-th harmonic voltage vector; $\varphi_{k}$ - the phase difference between the voltage and current vectors of the $k$-th harmonic.

A non-linear current is the difference between the measured current and the calculated ideal current:

$$
I_{n L}(t)=i(t)-i_{L}(t),
$$

where $i(t)$ - the measured current.

A comparative analysis of these methods of distortion source detection is given in [13].

In the above described harmonic sources detection methods all measurements are made at the PCC. The second and third of the listed distortion sources detection methods in the DS are founded on the assumption of linearity of the load impedance at all frequencies, which is not entirely correct. For example, presence of the harmonic filter reduces to zero this assumption. Most universal is the power flux sense method generated by the harmonic source, since only measured values are used there without any assumptions. The drawback of power flux sense method is the lack of consideration of the mutual fluxes of the distortion power that arise when there are several harmonic sources in the DS [20]. Actually, the EMF of harmonic sources can have various values and internal impedances. When measuring of the harmonics voltage in the PCC, we get some total value - the resultant value impact of all distortion sources in the network.

To minimize the effect of mutual compensation of secondary powers a method for detecting harmonics power flux using the technology of distributed measurements is proposed in [21-23].

As a method of harmonic analysis, the Fast Fourier Transform is used in most cases to detection distortion sources, which does not allow reliably identify the distortion sources and the degree of participation of each subject of DS in the distribution of secondary power of higher harmonics in the case of an fastvariable nonlinear load. Application the wavelet transforms solves this problem only partially due to problem the transition from wavelet coefficients to harmonics. Hence, for reliable identify of distortion sources and the degree of participation of each DS`s subject in distribution of harmonics power relevant problem of choosing the method of harmonic analysis.

Objectives and purposes of study. The purpose of this work is to increase the reliability identify of distortion sources and increase reliability of detecting the degree of participation of each subject of DS in distribution of harmonics power.

To achieve this purpose, it is necessary to solve the following tasks:

- create a model of DS with several fast-variable sources of harmonics;

- measure the magnitude and sign of the harmonics power, at all connection points of the DS`s subjects;

- to draw conclusions from the results of measurements.

Results of study. A feature of the FFT is that with this conversion all components of the output spectrum of the signal are calculated at once. As a result, the original signal $x(t)$ is represented as sine`s sum (harmonics) of various frequencies:

$$
x(t)=A_{1} \sin \left(\omega t+\alpha_{1}\right)+A_{2} \sin \left(2 \omega t+\alpha_{2}\right)+\mathrm{K}+A_{n} \sin \left(n \omega t+\alpha_{n}\right),
$$

where $A_{1}, A_{2}, \ldots, A_{n}$ - the amplitudes harmonic components of signal $x(t) ; \omega$ - the angular frequency; $\alpha_{1}, \alpha_{2}, \ldots \alpha_{n}$-the harmonic components phase angle of the signal; $n$ - the maximum harmonics order. 
It can be argued that the FFT is an indicator of the presence of certain harmonic components in the signal [24].

According to [25], for distribution systems with a frequency of $50 \mathrm{~Hz}$, an 10 periods of the fundamental harmonic is taken as sample interval for measuring the power quality indicators.

With the aim of detail the frequency content of the signal in the sample interval, we make computation the spectrum points obtained as a result of the FFT applying the Discrete Fourier Transform (DFT) (Fig. 1).

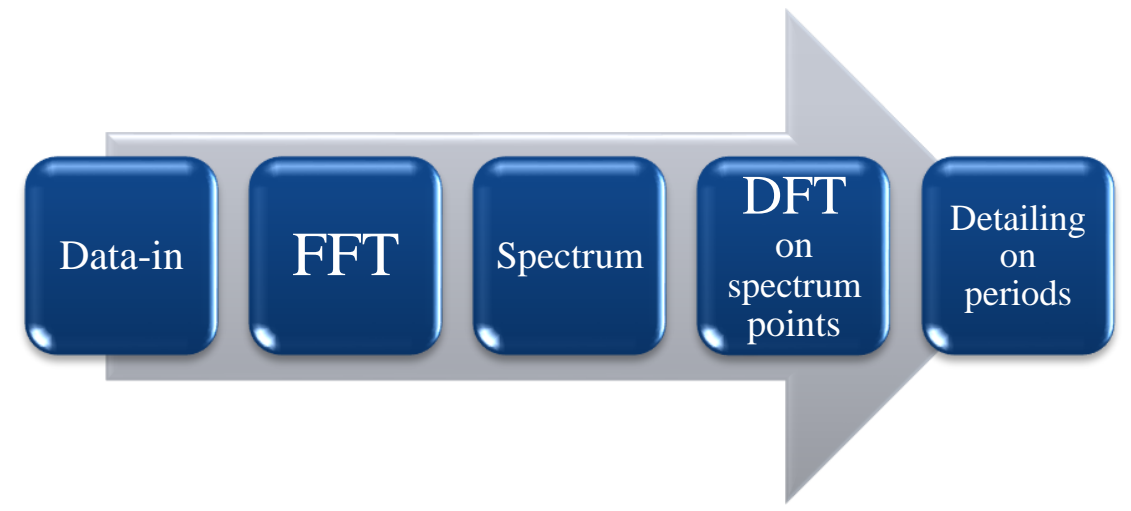

Figure 1. Improvement of the harmonic analysis method [24]

The possibility to analyze the source signal for each harmonic separately is a specific feature of the DFT with respect to the FFT.

To do this, multiply each period of the signal by sine and cosine of individual amplitude with frequencies obtained as a result of the FFT signal and integrate over the interval $2 \pi$. As a result, for each harmonic component on the $l$-th period of the sample interval, we obtain a set of equations [24]:

$$
\left\{\begin{array}{l}
A_{k l} \pi \cos \alpha_{k l}=a_{k l} \\
A_{k l} \pi \sin \alpha_{k l}=b_{k l},
\end{array}\right.
$$

where $A_{k l}$, - the amplitude of the $k$-th harmonic on the $l$-th period of the sample interval; $k$-harmonic order; $l=1 \div 10$ - the serial number of the measurement interval period; $\alpha_{k l}$ - the phase angle of the $\mathrm{k}$-th harmonic at the 1-th sample interval period; $\alpha_{k l}$ - the integral sum over the interval $2 \pi$ of product of the signal by the individual amplitude sine of the $k$-th harmonic on the $l$-th of the sample interval period; $b_{k l}-$ the integral sum over the interval $2 \pi$ of product of the signal by the individual amplitude cosine of the $k$-th harmonic on the $l$ th of the sample interval period.

The set of equations (13) is a trigonometric form of a complex number $z_{k l}=a_{k l}+j b_{k l}$. Then the amplitude of the $k$-th harmonic on the $l$-th sample interval period:

$$
A_{k l}=\frac{\left|z_{k l}\right|}{\pi},
$$

where $\left|z_{k l}\right|-$ the absolute value of the complex number $z_{k l}$.

The phase angle of the $k$-th harmonic on the $l$-th sample interval period:

$$
\alpha_{k l}=\arg z_{k l},
$$

where $\arg z_{k l}$ - the argument of the complex number $\underline{z} k$.

Thus possible to localize the moments of beginning and ending occurrence of the higher harmonics accurate to one period of the fundamental frequency.

For the current and voltage measured at the connection nodes of the DS subjects, on the sample interval we have complex current and voltage matrixes for each harmonic:

$$
\begin{gathered}
\dot{U}_{\boldsymbol{k}}=\left[\begin{array}{llllll}
\dot{U}_{k 1} & \dot{U}_{k 2} & \ldots & \dot{U}_{k l} & \ldots & \dot{U}_{k 10}
\end{array}\right], \\
\dot{\boldsymbol{I}}_{\boldsymbol{k}}=\left[\begin{array}{lllllll}
\dot{I}_{k 1} & \dot{I}_{k 2} & \ldots & \dot{I}_{k l} & \ldots & \dot{I}_{k 10}
\end{array}\right],
\end{gathered}
$$

where $\dot{\boldsymbol{U}}_{\boldsymbol{k}}$-complex voltages matrix of the $k$-th harmonic on the measurement interval; $\dot{\boldsymbol{I}}_{\boldsymbol{k}}$-complex currents matrix of the $k$-th harmonic on the measurement interval; $\dot{U}_{k l}$ - the complex value of the $k$-th harmonics voltage on the $l$-th period of the sample interval; $\dot{I}_{k l}$-the complex value of the $k$-th harmonics current on the $l$-th period of the sample interval; $l=1 \div 10$ - serial number of the period on the sample interval; $k$ - harmonic order. 
The active power of the $k$-th harmonic is:

$$
P_{k}=U_{k} I_{k} \cos \varphi_{k},
$$

where $U_{k}$ - the rms value of the $k$-th harmonics voltage; $I_{k}$-the rms value of the $k$-th harmonics current; $\varphi_{k}-$ the phase difference between the voltage and current of the $k$-th harmonic; $k$-harmonic order.

Elementwise multiplication (16) by (17), using expression (18), given us the scalar matrix of the $k$-th harmonics active power on the sample interval:

$$
\mathbf{P}_{\mathbf{k}}=\left[\begin{array}{llllll}
P_{k 1} & P_{k 2} & \Lambda & P_{k l} & \Lambda & P_{k 10}
\end{array}\right],
$$

where $P_{k l}$ - the active power of the $k$-th harmonic on the $l$-th period of the sample interval; $k$ - harmonic order; $l=1 \div 10-$ serial number of the period on the sample interval.

Since, in the case of an fast-variable nonlinear load, the magnitude and sign of the harmonics power flux at the sample interval vary, then the arithmetic mean value of the elements of the matrix (17) is taken as the power of the $k$-th harmonic on the sample interval:

$$
P_{k}^{D F T}=\frac{1}{10} \sum_{l=1}^{10} P_{k l} .
$$

In the case of a steady state nonlinear load, the power of the $k$-th harmonic consumed or generated by the $i$-th subject of the DS, calculated using the FFT and the power of the $k$-th harmonic calculated by the described algorithm using of the DFT on periods will be the same:

$$
P_{k i}^{F F T}=P_{k i}^{D F T},
$$

where $P_{k i}^{F F T}$ - the $k$-th harmonics power of the $i$-th DS`s subject, calculated using FFT algorithm; $P_{k i}^{D F T}-$ the $k$-th harmonics power of the $i$-th DS`s subject, calculated using DFT on periods algorithm.

Symptom of the fast-variable nonlinear load is the inequality:

$$
\frac{P_{k i}^{F F T}}{P_{k i}^{D F T}} \neq 1
$$

For a correct distribution of compensation payments, it is expedient to determine not only the sources of distortions, but to estimate the degree of participation of each DS`s subject in the distribution of the harmonics power. As a participation criterion of each DS subject in distribution of the harmonics power, the distribution coefficient by $k$-th harmonic is used - the ratio of the $k$-th harmonic active power of each subject of DS to the aggregate active power of the corresponding harmonic generated by all distortion sources, taking into account the sign [23].

The formula for determining the distribution coefficient of the $i$-th DS`s subject by the $k$-th harmonic:

$$
K_{k i}^{D F T}=\frac{P_{k i}^{D F T}}{P_{\Sigma k}^{D F T}}
$$

where $P_{\Sigma k}^{D F T}$ - the $k$-th harmonics aggregate power, calculated using DFT on periods algorithm.

The value of $P_{\Sigma k}^{D F T}$ is the sum of the active powers of all the sources of the $k$-th harmonic calculated using the DFT on periods algorithm:

$$
P_{\Sigma k}^{D F T}=\sum P_{\text {kisource }}^{D F T},
$$

where $P_{k i s o u r s e}^{D F T}$ - the power of the $i$-th source of the $k$-th harmonic, calculated using the DFT on periods algorithm. $P_{\text {kisourse }}^{D F T}$ is determined from the condition:

$$
P_{k i s o u r c e}^{D F T}=\left\{\begin{array}{l}
0 \text { if } P_{k i}^{D F T} \geq 0 \\
P_{k i} \text { if } P_{k i}^{D F T}<0
\end{array},\right.
$$

where ${ }^{P_{k i}^{D F T}}$ - the $k$-th harmonics power of the $i$-th DS`s subject, calculated using DFT on periods algorithm.

At the fig. 2 an algorithm is presented that allows to determine the type of distortion source (fastvariable or steady state) and the degree of participation of each DS`s subject in the distribution of harmonics power, as well as other additional information that allows to optimize the operation of the distribution system. 


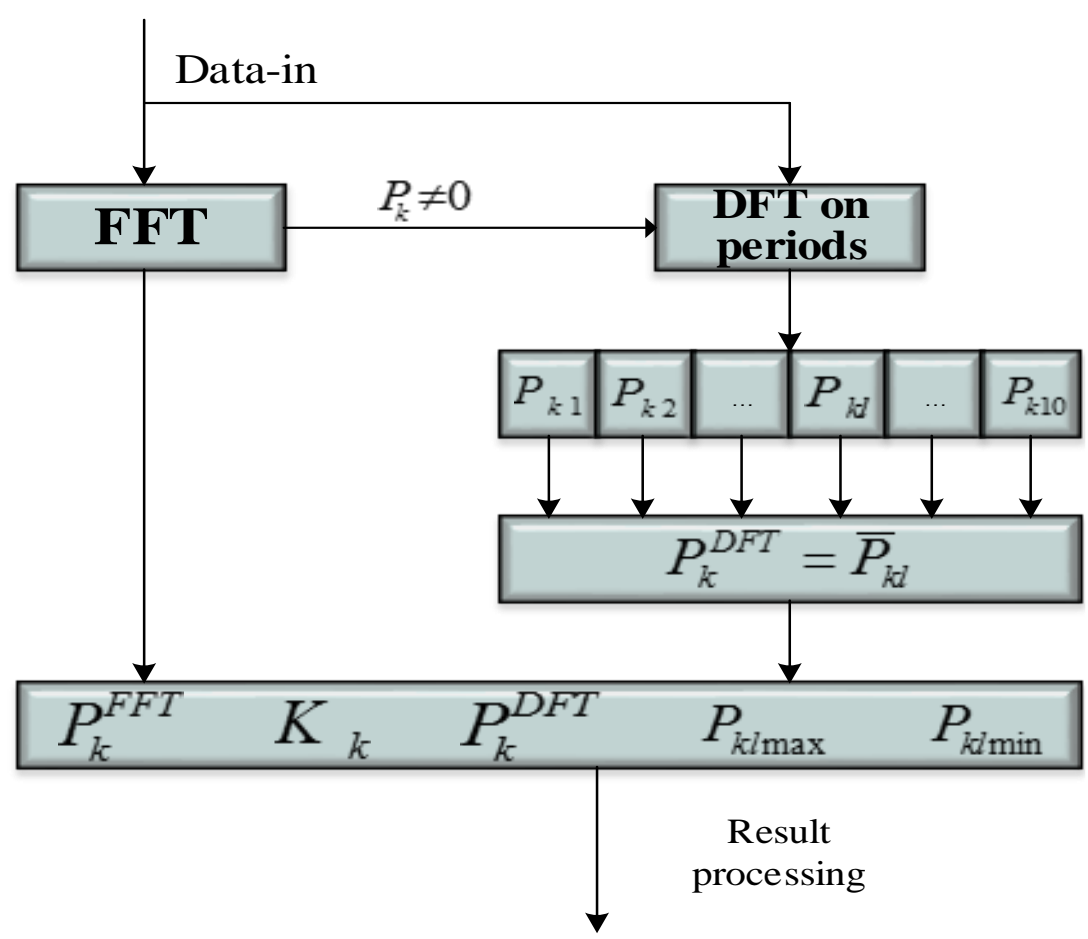

Figure 2. Algorithm of the method for determining the type of distortion source and the degree of participation of each DS`s subject in distribution of harmonics power at the sample interval

For the study, the DS scheme was simulated, with sources of the 3rd harmonic (Fig. 3).

The circuit is powered from the source $110 \mathrm{kV} 50 \mathrm{~Hz}$ via the step-down transformer $110 / 10 \mathrm{kV} 40$ MVA. EMF $E_{1}, E_{2}$, loads 1 and 2, the switches $S W 1$ and $S W 2$ form a distortion sources, in which the loads 1 and 2 themselves is an internal resistance, and the switches $S W 1$ and $S W 2$ simulating the fast-variable sources of distortion.

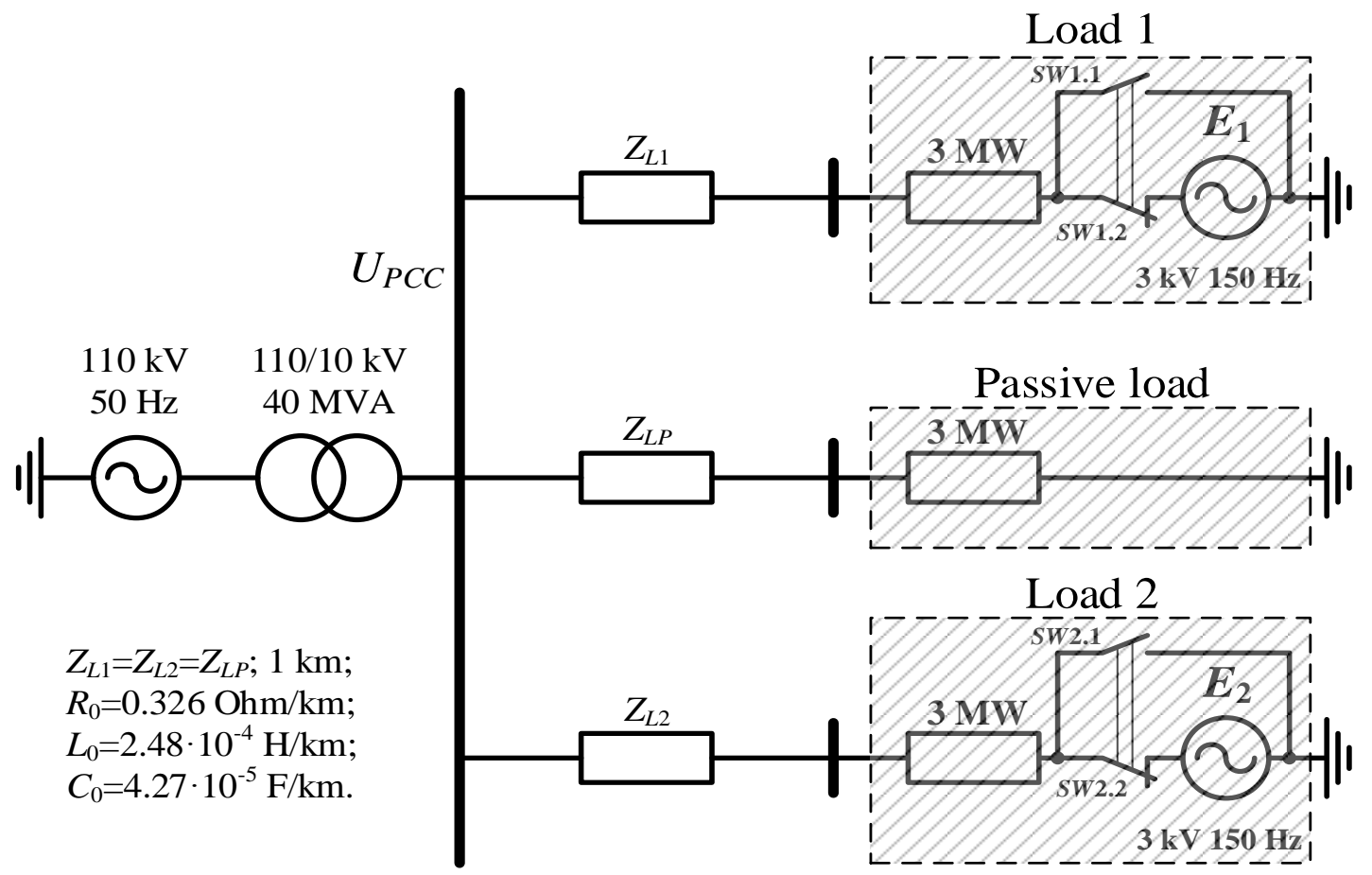

Figure 3. Schematic diagram of the DS's model with two distortion sources $E_{1}$ and $E_{2}$, where $Z_{L 1}, Z_{L 2}, Z_{L P}-$ the impedance of the cables lines, which supplying the load 1, load 2 and passive load; $E_{1}, E_{2}$-EMF of harmonics generated in load 1 and load 2, respectively; $S W 1, S W 2$ - switches that model the variable source of distortion 
For the analysis of this DS`s model, the following operation modes were chosen:

1. $E_{1}=6000 \mathrm{~V}$ with phase $0^{\circ}$ and $E_{2}=3000 \mathrm{~V}$ with phase $0^{\circ}\left(E_{1}\right.$ and $E_{2}$ are in-phase $)$. In this mode, $\mathrm{E}_{2}$ operates over the entire sample interval, and $\mathrm{E}_{1}$ during the first five periods of the fundamental frequency, i.e., half the sample interval (Fig. 4a).

2. $E_{1}=6000 \mathrm{~V}$ with phase $0^{\circ}$ and $E_{2}=3000 \mathrm{~V}$ with phase $180^{\circ}$ ( $E_{1}$ and $E_{2}$ are opposite). In this mode, $E_{2}$ operates over the entire sample interval, and $E_{1}$ during the first five periods of the fundamental frequency, i.e., half the sample interval (Fig. 4b).

3. $E_{1}=30000 \mathrm{~V}$ with phase $0^{\circ}$ and $E_{2}=3000 \mathrm{~V}$ with phase $0^{\circ}\left(E_{1}\right.$ and $E_{2}$ are in-phase). In this mode, $E_{2}$ operates over the entire sample interval, and $E_{1}$ over only first period of the fundamental frequency (1/10 of the sample interval), i.e., the overvoltage caused by the harmonic source (Fig. 4c).

4. $E_{1}=6000 \mathrm{~V}$ with phase $0^{\circ}$ and $E_{2}=6000 \mathrm{~V}$ with a phase of $180^{\circ}\left(E_{1}\right.$ and $E_{2}$ are opposite). In this mode, $E_{1}$ operates over the first five periods of the fundamental frequency harmonic at the sample interval, and $E_{2}$ over the remaining five periods of the fundamental frequency, i.e., the distorting effect of harmonic sources at the sample interval is separate by time (Fig. 4d).

The magnitude and sign of the 3rd harmonic power were studied at the sample interval, depending on the distortion source power, the effect duration, the location in the network, and the measurement point. The measurements were doing in the PCC and at the connecting terminals of all DS subjects. For detection the harmonic spectrum of the current and voltage, was used the FFT and DFT on periods algorithms. The active power of the k-th harmonic, consumed by the i-th cable line, is defined as the difference between the power measured at the beginning of the line (PCC) and at the end of the line (consumer terminals) [23]:

$$
P_{L i k}=P_{i k P C C}-P_{i k} \text {, }
$$

where $P_{i k}$ - the active power of the $k$-th harmonic of the $i$-th consumer.

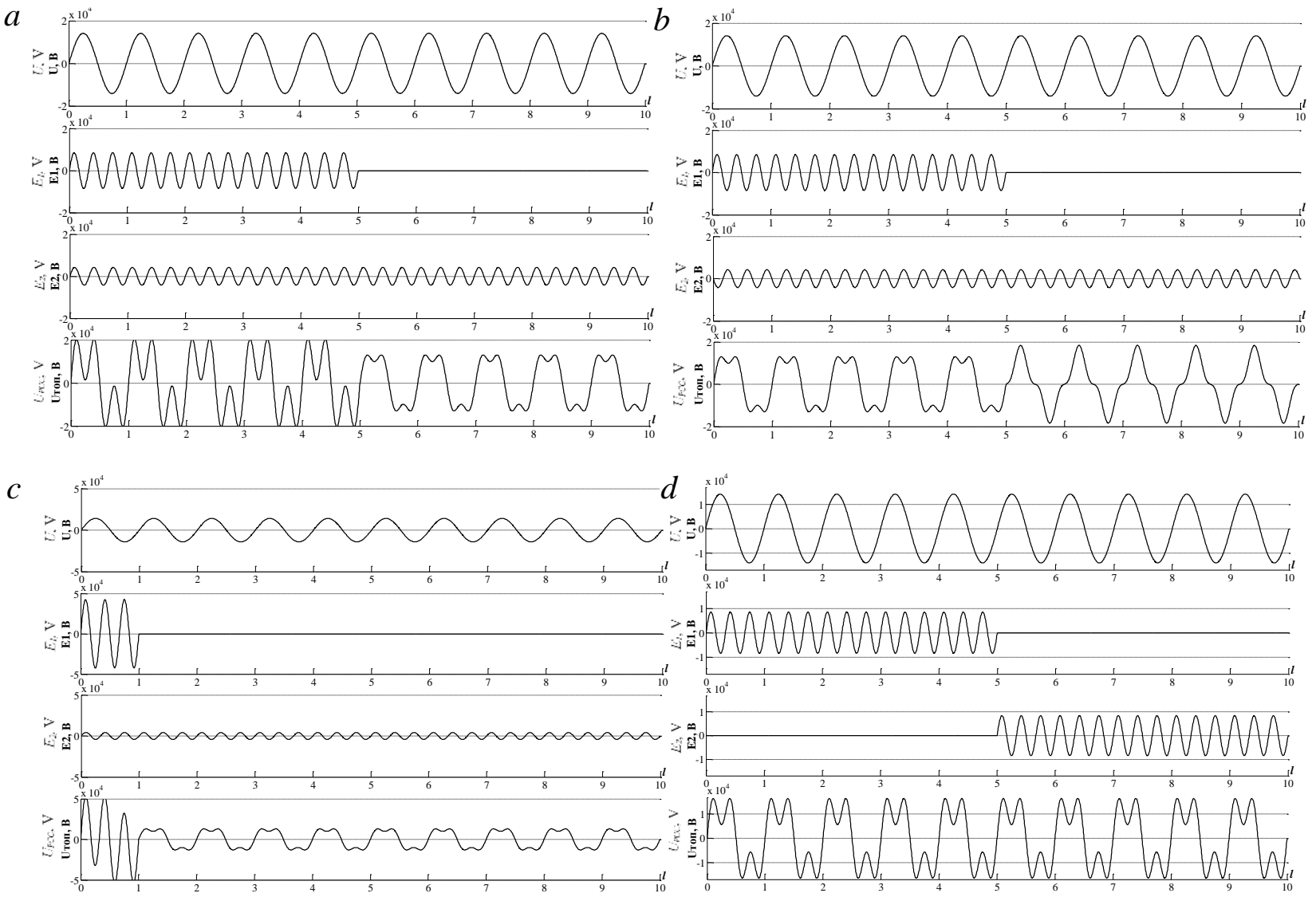

Figure 4. Diagrams of the effect of distorting loads on the voltage waveform at the PCC for mode 1 (a), mode 2 (b), mode 3 (c), and mode 4 (d), where $U$-the fundamental harmonics voltage, $E_{1}$ - the distortion

EMF distortion in load 1; $E_{2}$ - EMF distortion in load $2 ; 1$ - the serial number of the period of the fundamental harmonic at the sample interval 
ISSN 1813-5420 (Print). Енергетика: економіка, технологіï, екологія. 2018. № 2

The results are shown in Table 1.

Table 1.

The power of the 3rd harmonic of all subjects of model of DS for the different operating modes

\begin{tabular}{|c|c|c|c|c|}
\hline Parameter & Mode 1 & Mode 2 & Mode 3 & Mode 4 \\
\hline$P_{31}^{F F T}$ & $-3186,75$ & $-1170,5$ & $-2780,43$ & $-1134,35$ \\
\hline$P_{31}^{D F T}$ & $-6287,27$ & $-4159,63$ & $-30273,6$ & $-4489,62$ \\
\hline$P_{32}^{F F T}$ & $-3192,28$ & $-1204,74$ & $-2791,08$ & $-1197,58$ \\
\hline$P_{32}^{D F T}$ & $-2425,47$ & $-461,24$ & 4161,435 & $-4559,01$ \\
\hline$P_{3 P}^{F F T}$ & 3121,95 & 0 & 3204,146 & 0 \\
\hline$P_{3 P}^{D F T}$ & 3888,391 & 744,3795 & 10153,96 & 2977,518 \\
\hline$P_{3 S Y S}^{F F T}$ & 520,1117 & 0 & 410,0289 & 0 \\
\hline$P_{3 S Y S}^{D F T}$ & 685,0428 & 152,5759 & 1860,712 & 610,3036 \\
\hline$P_{3 L 1}^{F F T}$ & 1378,522 & 1170,5 & 1113,63 & 1134,346 \\
\hline$P_{3 L 1}^{D F T}$ & 2702,909 & 2490,717 & 12872,03 & 2708,001 \\
\hline$P_{3 L 2}^{F F T}$ & 1380,854 & 1204,739 & 1125,754 & 1197,581 \\
\hline$P_{3 L 2}^{D F T}$ & 1419,835 & 1199,471 & 1316,631 & 2617,886 \\
\hline$P_{3 L P}^{F F T}$ & $-22,4045$ & 0 & $-282,055$ & 0 \\
\hline$P_{3 L P}^{D F T}$ & 16,56659 & 33,7301 & $-91,217$ & 134,9204 \\
\hline
\end{tabular}

When analyzing the results, we saw a significant difference in the third harmonic power, calculated using FFT and calculated using DFT by periods. Moreover, for all subjects of the DS model the power of the 3rd harmonic, calculated using DFT on periods, greater in magnitude than the power of the third harmonic calculated using FFT. We can be concluded, that in case of an fast-variable nonlinear load when using only FFT, there is an underestimation of damage to the DS`s electrical equipment. It is also noteworthy, that for modes 1 and 3 in the case using FFT, the cable line feeding the passive load is detecting as a harmonic distortion source, which does not match to the physical properties of this DS`s subject.

Conclusions:

- for detection of distortion sources is advisable to use the harmonic power flux method with using the technology of distributed measurements;

- "transit" elements of DS (transformers, cable lines) are consumers/generators of harmonics active power;

- existing methods of harmonic analysis do not allow authentically detection the distortion sources and the degree of participation of each subject of DS in the distribution of the harmonics power in the presence of fast-variable nonlinear loads in DS;

- to increase authentically detection of distortion sources and the degree of participation of DS`s subjects in the distribution of the harmonics power in the case of fast-variable distorting loads, it is necessary to jointly use the FFT and DFT algorithms on points of spectrum, obtained as a result of the FFT.

\section{References:} 2011.

[1] Power Quality Harmonics Analysis and Real Measurements Data, Ed. by Prof. G. Romero. InTech,

[2] N. N. Kharlov. Electromagnetic compatibility in the power industry. Tomsk: TPU Publishin, 2007.

[3] A. V. Voloshko and D. V. Filyanin. The impact of power quality on the accuracy of meter reading: areview of study. Transactions of Kremenchuk Mikhailo Ostrohradskyi National University, vol. 4 (87), 2014, pp. $38-43$.

[4] J. Manson and R. Targosz. European Power Quality Survey Report. November 2008. Available: http://www.leonardo-energy.org/sites/leonardo-energy/files/root/pdf/2009/PQSurvey.pdf ～(accessed 04 January 2016).

[5] EN 50160:2014. Voltage characteristic of electricity supplied by public electricity network (EN 50160 2010, IDT). K: Ministry of economic and trade of Ukraine, 2014. 
[6] IEEE Std 1459-2010. Definitions for the measurement of electric power quantities under sinusoidal, nonsinusoidal, balanced, or unbalanced conditions. IEEE Standard 1459, 2010.

[7] V. E. Tonkal V. E., A. V. Novoseltsev and other. Energy balance in electrical circuits. K.: Naukova dumka, 1992.

[8] A. Ferrero, A. Menchetti and R. Sasdelli. Measurement of the Electric Power Quality and Related. European Transactions on Electric Power. V. 6, № 6, 1996, pp. 401-406.

[9] L. S. Czarnecki, T. Świetlicki. Power in nonsinusoidal networks, their analysis, interpretation and measurement. IEEE Trans. Instrum. Measur. V. 39, № 2, 1990, pp. 340-345.

[10] A. E. Emanuel. On the Assessment of Harmonic Pollution. IEEE Transaction on Power Delivery. V. 10, № 3, 1995, pp. 1693-1698.

[11] P. J. Rens and P. H. Swart. On Techniques for the Localization of Multiple Distortion Sources in Three-Phase Networks: Time Domain Verification. ETEP. V. 11, № 5, 2001, pp. 317-322.

[12] P. H. Swart, M. J. Case and J. D. Van Wyk. On Techniques for Localization of Sources Producing Distortion in Electric Power Networks. ETEP. V. 4, № 6, 1994, pp. 485-490.

[13] R. S. Herrera, A. Pérez, P. Salmerón, J. R. Vázquez and S. P. Litrán Distortion Sources Identification in Electric Power Systems. Department of Electrical Engineering E.P.S., Huelva University. Available: http://www.uhu.es/geyer/Congresos_inter/congresos\%20internacionales/CI_61.pdf. (accessed 20 January 2016).

[14] G. T. Heydt. Identification of Harmonic Sources by a State Estimation Technique. IEEE Trans. On Power Delivery. V. 4, № 1, 1989, pp. 569-576.

[15] L. F. Beites, M. Alvarez and A. Díaz. Sensor optimum location algorithm for estimating harmonic sources injection in electrical networks. International Conference on Renewable Energies and Power Quality (ICREPQ'14). Cordoba, Spain, 8-10 April, 2014. Available: http://www.icrepq.com/icrepq'14/315.14-Beites.pdf. (accessed 20 January 2016).

[16] A. S. Stepanov, V. I. Marugin. On the observability of electricity distribution networks. Power engineering, ecology, reliability, safety: Proceedings of the VII All-Russian Scientific and Technical Conference. Tomsk, 2010, pp. 46-48.

[17] F. A. Zykin. Determining of impact consumers in the power quality distortion. Electrichestvo, vol. 11, 1992, pp. 13-19.

[18] K. Srinivasan. On Separating Customer and Supply Side Harmonic Contributions. IEEE Trans. on Power Delivery. V. 11, № 2, 1996, pp. 1003-1012.

[19] A. Dell'Aquila, M. Marinelli, V. G. Monopoli and P. Zanchetta. New Power-Quality Assessment Criteria for Supply under Unbalanced and Nonsinusoidal Conditions. IEEE Trans. on Power Delivery. V. 19, № 3, 2004, pp. 1284-1290.

[20] G. A. Senderovich. Determination of share participation of subjects in responsible in making unbalanced condition. Naukovi pratsi Donetskogo Natsionalnogo Tekhnichnogo Universytetu, vol. 11(186), 2011, pp. 330-335.

[21] Voloshko Anatoly V., Filyanin Daniel V. To the issue distortion source identification on the example of simplified model of electric power system. Bulletin of the Tomsk Polytechnic University. Geo Assets Engineering, V. 326, № 6, 2015, pp. 114-121.

[22] A. V. Voloshko, D. V. Filyanin. Distortion source identification in the point of common coupling on the example of simplified model of electric power system. POWER ENGINEERING: Economics, Technique, Ecology, № 1(39), 2015, pp. 35-43.

[23] A. V. Voloshko, D. V. Filyanin. Distortion source identification and impact of each subjects of power supply system at harmonics power distribution. Transaction of the Kharkiv Petro Vasilenko National Technical University of Agriculture. Technical sciences. "Problems of energy supply and energy saving in the agroindustrial complex of Ukraine". № 165, 2015, pp. 14-15.

[24] A. V. Voloshko, D. V. Filyanin. Detection and localizatin of power quality disturbanses based on Fast Fourier Transform and Discrete Fourier Transform. POWER ENGINEERING: Economics, Technique, Ecology, № 3, 2017, pp. 87-94.

[25] EN 61000-4-30:2009. Electromagnetic compatibility (EMC). Part 4-30: Testing and measurement techniques - Power quality measurement methods (IEC 61000-4-30:2008). BSI, Approved 30 April 2009.

\section{УДК 621.311}

Д. В. Філянін, асистент, ORCID 0000-0003-3576-3633

Національний технічний університет України «Київський політехнічний інститут імені Ігоря Сікорського» ВИЗНАЧЕННЯ ДЖЕРЕЛ ГАРМОНІЧНИХ СПОТВОРЕНЬ В СИСТЕМАХ

ЕЛЕКТРОПОСТАЧАННЯ 3 ВИКОРИСТАННЯМ АЛГОРИТМУ ДИСКРЕТНОГО ПЕРЕТВОРЕННЯ ФУР'Е ЗА ПЕРІОДАМИ

Наявність нелінійних навантажень $і$ зростання числа систем розподіленої генерації електроенергї призводять до спотворення форми кривих напруги і струму в системах електропостачання (СЕП), тобто

ISSN 2308-7382 (Online) 
до появи гармонік струму і напруги. При иьому енергосистема зобов'язана поставляти електроенергію тільки основної частоти 50Ги з постійною амплітудою. Енергопостачальні організації зазвичай знімають з себе відповідальність за причини виникнення гармонік, вводячи стандарти або рекомендачії щзодо обмеження рівнів гармонійних складових в точках загального приєднання споживачів. Ці документи не враховують склад обладнання СЕП $і$, відповідно, збитки, яких можуть завдати гармоніки мережевому обладнанню та устаткуванню споживача. Актуальність роботи обумовлена необхідністю достовірного визначення джерел гармонічних спотворень в СЕП для ефективного функціонування системи штрафів $i$ санкиій $і$ більш ефективного визначення списку технічних заходів щодо підвищення якості електроенергії. У статті проведено огляд існуючих методів визначення джерел спотворення в СЕП. В якості методу гармонійного аналізу при визначенні джерел спотворень в більшості випадків використовується Швидке Перетворення Фур'є (ШПФ), яке в разі різкозмінного нелінійного навантаження не дозволяє достовірно визначати джерела спотворення і ступінь участі кожного суб'єкта СЕП в розподілі потужності вищих гармонік. 3 метою деталізачії частотного наповнення сигналу на інтервалі вимірювання було проведено розрахунок точок спектру, отриманих в результаті ШПФ, використовуючи Дискретне Перетворення Фур'є (ДПФ). На прикладі моделі розподільчої мережі запропоновано новий підхід до визначення джерел гармонік по методу, заснованому на вимірюванні знака і величини спотворюючої потужності, щзо визначена за допомогою алгоритму Дискретного Перетворення Фур'є за періодами.

Ключові слова: якість електроенергії, гармоніки, коефіцієнт гармонік, джерело спотворення, Швидке Перетворення Фур'є, Дискретне Перетворення Фур'є.

УДК 621.311

Д. В. Филянин, ассистент, ORCID 0000-0003-3576-3633

Национальный технический университет Украины

\section{ОПРЕДЕЛЕНИЕ ИСТОЧНИКОВ ГАРМОНИЧЕСКИХ ИСКАЖЕНИЙ В СИСТЕМАХ ЭЛЕКТРОСНАБЖЕНИЯ С ИСПОЛЬЗОВАНИЕМ АЛГОРИТМА ДИСКРЕТНОГО ПРЕОБРАЗОВАНИЯ ФУРЬЕ ПО ПЕРИОДАМ}

Наличие нелинейных нагрузок и рост числа систем распределенной генерации электроэнергии приводят к искажению формы кривых напряжения и тока в системах электроснабжения (СЭС), то есть к появлению гармоник тока и напряжения. При этом энергосистема обязана поставлять электроэнергию только основной частоты 50Ги с постоянной амплитудой. Энергоснабжсающие организации обычно снимают с себя ответственность за причины возникновения гармоник, вводя стандарты или рекомендации по ограничению уровней гармонических составляющих в точках общего присоединения потребителей. Эти документы не учитывают состав оборудования СЭС и, соответственно, убытки, которые могут нанести гармоники сетевому оборудованию и оборудованию потребителя. Актуальность работь обусловлена необходимостью достоверного определения источников гармонических искажений в СЭС для эффективного функционирования системы штрафов и санкций и более эффективного определения списка технических мероприятий по повышению качества электроэнергии. В статье проведен обзор существующих методов определения источников искажения в СЭС. В качестве метода гармонического анализа при определении источников искажений в большинстве случаев используется Быстрое Преобразование Фурье (БПФ), которое в случае резкопеременной нелинейной нагрузки не позволяет достоверно определять источники искажения и степень участия каждого субъекта СЭС в распределении мощности высших гармоник. С иелью детализаџии частотного наполнения сигнала на интервале измерения был проведен расчет точек спектра, полученных в результате БПФ, используя Дискретное Преобразование Фурье (ДПФ). На примере модели распределительной сети предложен новый подход к определению источников гармоник по методу, основанному на измерении знака и величины искажающей мощности, определенной $c$ помощью алгоритма Дискретного Преобразования Фурье по периодам.

Ключевые слова: качество электроэнергии, гармоники, коэффициент гармоник, источник искажения, Быстрое Преобразование Фурье, дискретное преобразование Фурье. 